\title{
Hubungan Inisiasi Menyusu Dini dan Rawat Gabung dengan Produksi Air Susu Ibu pada Postpartum di RSU Anutapura Palu
}

\author{
Widya Pani \\ Prodi D-III Kebidanan Palu, Jurusan Kebidanan Poltekkes Kemenkes Palu \\ *Email korespondensi: widyapani.wp@gmail.com
}

Article Info

Article history:

Submitted: 2019-02-25

Accepted: 2019-04-16

Published: 2019-04-22

Keywords:

Early breastfeeding initiation; care for joining; mother's milk production

\section{ABSTRACT}

Early Initiation of Breastfeeding can prevent infant mortality, especially in developing countries. IMD practices can prevent $22 \%$ of newborn mortality. One of the reasons mothers do not give IMD is the absence of breast milk and the amount of breast milk that is considered lacking, so the mother gives formula milk. Mothers don't take care of joining because they don't breathe spontaneously and hypothermia. The purpose of this study was to find out the relationship of early breastfeeding initiation and care to join with the production of breast milk at post partum at the Anutapura General Hospital in Palu. The method is analytic with a cross sectional approach. The population and samples in this study were post partum at Anutapura Palu Hospital at the time of the study, which amounted to 96 people, with a purposive sampling technique. The analysis used in this study used fisher exact statistical tests. The results showed that of 96 IMD respondents as many as 75 respondents $(78.1 \%)$, and not IMD as many as 21 respondents (21.9). Mothers who did join care were 76 respondents $(79.2 \%)$, and mothers who did not take care of as many as 20 respondents (20.8). "Fisher's exact test" test results $p$ value: 0,000 ( $p$ value $\leq 0.05$ ). Adequate ASI production was 77 respondents $(80.2 \%)$, and inadequate ASI production was 19 respondents (19.8). Fisher's exact test results $p$ value: 0,000 ( $p$ value $\leq 0,05$ ). The conclusion is that there is a relationship between early breastfeeding initiation and admission to joining breast milk production at post partum. Suggestions are expected for midwives at Anutapura Hospital in Palu City to further improve counseling about the importance of Early Breastfeeding Initiation and the importance of nursing care for mothers and babies.

\section{PENDAHULUAN}

Pemberian air susu ibu secara ekslusif pada bayi sejak usia 0 bulan sampai dengan 6 bulan bermanfaat untuk tumbuh kembang bayi, serta antibodi yang bisa membantu bayi membangun sistem kekebalan tubuh dalam masa pertumbuhanya.Berkaitan dengan pemberian Air Susu lbu (ASI) Eksklusif selama enam bulan, proses Inisiasi Menyusu Dini (IMD) ini menjadi salah satu faktor penentu keberhasilannya karena IMD dapat mencegah kematian bayi, terutama dinegara berkembang. ${ }^{1}$ Praktek IMD dapat mencegah $22 \%$ angka kematian bayi baru lahir, sehingga untuk mengurangi angka kematian bayi baru lahir, Word Health Organization (WHO) merekomendasikan para ibu untuk memberikan kolostrum saja dalam satu jam pertama kehidupan bayi. Berbagai upaya telah dilakukan untuk mempromosikan pemberian ASI Eksklusif. Tetapi untuk IMD, masih sedikit materi yang sampai kepada ibu-ibu, baik melalui kader kesehatan maupun petugas 
kesehatan di sekitar tempat tinggalnya. Bahkan hanya di beberapa rumah sakit bersalin (di kota besar) dapat ditemukan layanan IMD untuk ibu melahirkan. ${ }^{2}$

Inisiasi menyusu dini masih sulit diterapkan karena kebanyakan ibu tidak tahu bahwa inisiasi menyusu dini sangat bermanfaat, proses yang hanya memakan waktu satu jam tersebut berpengaruh pada sang bayi seumur hidup serta adanya beberapa pendapat yang tidak benar, diantaranya yaitu ibu menganggap bayinya akan kedinginan bila tidak segera dibedong, ibu terlalu lelah untuk segera menyusui bayinya, ibu takut jika bayinya jatuh, ibu merasa badan dan bayinya masih kotor sehingga harus dimandikan, kolostrum tidak keluar atau jumlah kolostrum tidak memadai sehingga diperlukan cairan lain, kolostrum tidak baik, bahkan berbahaya untuk bayi. ${ }^{3}$

Penelitian yang dilakukan oleh Lusje tentang hubungan rawat gabung dengan kelancaran ASI pada ibu post partum normal dengan hasil ibu yang dilakukan rawat gabung dan produksi ASInya lancar berjumlah 63 responden (70\%) sedangkan ibu yang tidak dilakukan rawat gabung namun produksi ASInya tidak lancar berjumlah 27 responden $(30 \%)$. Dapat dilihat bahwa ada hubungan rawat gabung dengan kelancaran ASI pada ibu post partum normal. ${ }^{4}$ Alasan ibu yang menjadi penyebab kegagalan praktek ASI eksklusif bermacam-macam. Anggapan yang paling sering berkembang di masyarakat adalah tidak keluarnya ASI dan jumlah ASI yang dianggap kurang. Hal ini membuat ibu panik karena merasa "kasihan" saat mendengar tangisan bayi. Maka keputusan yang diambil oleh ibu adalah memilih alternatif lain dengan memberikan susu formula. . $^{5,6}$

Berdasarkan data dari Rumah Sakit Anutapura Palu tahun 2014 jumlah persalinan sebanyak 2.767 persalinan dan ibu yang melakukan inisiasi menyusu dini dan rawat gabung sebanyak 1.720 orang (62,16\%), tahun 2015 jumlah persalinan sebanyak 2.468 persalinan dan yang melakukan inisiasi menyusu dini dan rawat gabung sebanyak 2.013 orang (81,6\%). Tahun 2016 dari bulan Januari sampai September jumlah persalinan sebanyak 1.989 orang dan ibu yang melakukan inisiasi menyusu dini dan rawat gabung sebanyak 1475 orang $(74,15 \%) .{ }^{7-9}$ Penelitian ini bertujuan untuk mengetahui hubungan IMD dan rawat gabung dengan produksi ASI pada post partum di Rumah Sakit Umum Anutapura Palu.

\section{METODE PENELITIAN}

Jenis penelitian analitik dengan menggunakan pendekatan cross sectional. Untuk melihat hubungan inisiasi menyusu dini dan rawat gabung dengan produksi Air Susu Ibu pada postpartum di Rumah Sakit Umum Anutapura Palu. Penelitian telah dilaksanakan pada tanggal 7 April sampai dengan tanggal 30 Mei 2018 di RSU Anutapura Palu. Populasi dalam penelitian ini adalah post partum yang ada di RSU Anutapura Palu pada saat penelitian dilakukan yang berjumlah 96 responden. Teknik pengambilan sampel dalam penelitian ini adalah purposive sampling, dengan kriteria inklusi dalam penelitian ini adalah semua ibu dengan riwayat persalinan spontan letak belakang kepala (LBK) dan post partum yang tidak memiliki kelainan puting susu. Pengumpulan sampel dengan cara melakukan pengamatan langsung dilapangan dengan menggunakan ceklist, Pada Inisisasi Menyusu dini dimana peneliti akan mengamati ketika bayi diletakkan didada ibu apakah bayi mampu mencari putting payudara ibu dalam kurun waktu 30 menit sampe 1 jam, Rawat gabung peneliti akan mengobservasi ibu dan bayi, sedangkan Kelancaran pengeluaran ASI, peneliti akan mengobservasi ibu tentang produksi ASInya. Analisis univariat dengan distribusi frekuensi dan analisis bivariat fisher exact test. 


\section{HASIL PENELITIAN}

Data sampel karakteristik ibu post partum terdiri dari umur, pendidikan dan pekerjaan pada tabel berikut ini :

Tabel 1. Distribusi Responden Berdasarkan Karakteristik lbu Post Partum Di Rumah Sakit Umum Anutapura

\begin{tabular}{lcc}
\hline Karakteristik responden & Frekuensi & Persentase (\%) \\
\hline Umur & 34 & 35,4 \\
17-25 Tahun & 43 & 44,8 \\
26-35 Tahun & 19 & 19,8 \\
36-45 Tahun & & \\
Pendidikan & 42 & 43,7 \\
Pendidikan Dasar (SD,SMP) & 33 & 34,4 \\
Pendidikan Menengah (SMA) & 21 & 21,9 \\
Pendidikan Tinggi & & \\
Pekerjaan & 4 & 4,1 \\
Bidan/perawat & 6 & 6,3 \\
Honorer & 78 & 81,3 \\
Ibu rumah tangga (IRT) & 1 & 1,0 \\
Mahasiswa & 6 & 6,3 \\
PNS & 1 & 1,0 \\
Swasta & & \\
\hline Sumbr: Data pimer, & & \\
\hline
\end{tabular}

Sumber: Data primer, 2018

Pada tabel 1 umur responden yang paling banyak adalah umur 26-35 Tahun yaitu sebanyak 43 responden $(44,8 \%)$ dan yang paling sedikit umur $36-45$ tahun sebanyak 19 responden (19,8\%). Pendidikan responden yang paling banyak adalah pendidikan dasar (SD,SMP) sebanyak 42 responen $(43,7 \%)$ dan pendidikan yang paling sedikit adalah pendidikan tinggi sebanyak 21 responden $(21,9 \%)$. Pekerjaan yang paling banyak adalah ibu rumah tangga (IRT) sebanyak 78 responden $(81,3 \%)$ dan yang paling sedikit adalah mahasiswa dan swasta sebanyak 1 responden (1\%).

Tabel 2. Distribusi Responden Berdasarkan Inisiasi Menyusu Dini, Rawat gabung dan Produksi ASI Pada Post Partum di Rumah Sakit Umum Anutapura Palu

\begin{tabular}{lcc}
\hline Variabel yang diteliti & Frekuensi & Persentase (\%) \\
\hline IMD & 75 & 78,1 \\
Ya & 21 & 21,9 \\
$\quad$ Tidak & & \\
Rawat gabung & 76 & 79,2 \\
$\quad$ Dirawat Gabung & 20 & 20,8 \\
$\quad$ Tidak Rawat gabung & & \\
Produksi ASI & 77 & 80,2 \\
$\quad$ Cukup & 19 & 19,8 \\
$\quad$ Tidak Cukup & & \\
\hline
\end{tabular}

Sumber: Data primer, 2018

Berdasarkan tabel 2 responden yang melaksanakan Inisiasi Menyusu Dini (IMD) sebanyak 75 responden $(78,1 \%)$, dan responden yang tidak melaksanakan Inisiasi Menyusu Dini (IMD) sebanyak 21 responden $(21,9)$. Responden yang melakukan rawat gabung sebanyak 76 responden $(79,2 \%)$, dan responden yang tidak melakukan rawat gabung sebanyak 20 responden $(20,8)$. Produksi ASI yang cukup 
sebanyak 77 responden $(80,2 \%)$, dan responden yang produksi ASI yang tidak cukup sebanyak 19 responden $(19,8)$.

Tabel 3. Hubungan IMD dan Riwayat Rawat Gabung dengan Produksi ASI pada Post Partum di Rumah Sakit Umum Anutapura Palu

\begin{tabular}{|c|c|c|c|c|c|}
\hline \multirow{3}{*}{ Variabel } & \multicolumn{4}{|c|}{ Produksi Air Susu } & \multirow{3}{*}{ Nilai $p$} \\
\hline & \multicolumn{2}{|c|}{ Cukup } & \multicolumn{2}{|c|}{ Tidak Cukup } & \\
\hline & $\mathbf{f}$ & $\%$ & $\mathbf{f}$ & $\%$ & \\
\hline \multicolumn{6}{|l|}{ IMD } \\
\hline Ya & 74 & 98,7 & 1 & 1,3 & \multirow{2}{*}{$<0,001$} \\
\hline Tidak & 3 & 14,3 & 18 & 85,7 & \\
\hline \multicolumn{6}{|l|}{ Rawat gabung } \\
\hline Ya & 75 & 98,7 & 1 & 1,3 & \multirow{3}{*}{$<0,001$} \\
\hline Tidak & 2 & 10,0 & 18 & 90,0 & \\
\hline Jumlah & 77 & 80,2 & 19 & 19,8 & \\
\hline
\end{tabular}

Pada tabel 3 menunjukkan bahwa dari 96 responden yang melakukan Inisiasi Menyusu Dini (IMD) sebanyak 75 responden, dimana sebanyak 74 responden $(98,7 \%)$ produksi ASInya cukup, 1 responden (1,3\%) produksi ASInya tidak cukup. Responden yang tidak melaksanakan IMD sebanyak 21 responden, dimana sebanyak 3 responden (14,3\%) produksi ASInya cukup dan 18 responden $(85,7 \%)$ produksi ASInya tidak cukup. Berdasarkan hasil uji "fisher's exact test" nilai p: $<0,001$ ( $p$ value $\leq 0,05$ ), maka $\mathrm{HO}$ ditolak dan Ha diterima yang artinya ada hubungan inisiasi menyusu dini dengan produksi ASI pada post partum di Rumah Sakit Umum Anutapura Palu.

Pada tabel 3 menunjukkan bahwa dari 96 responden, yang melakukan rawat gabung sebanyak 76 responden, dimana sebanyak 75 responden $(98,7 \%)$ produksi ASInya cukup, 1 responden (1,3\%) produksi ASInya tidak cukup. Responden yang tidak melakukan rawat gabung sebanyak 20 responden, dimana sebanyak 2 responden (10\%) produksi ASInya cukup dan 18 responden (90\%) produksi ASInya tidak cukup. Berdasarkan hasil uji "fisher's exact test" nilai $p<0,001$ ( $p$ value $\leq 0,05$ ), maka $\mathrm{HO}$ ditolak dan $\mathrm{Ha}$ diterima yang artinya ada hubungan rawat gabung dengan produksi ASI pada post partum di Rumah Sakit Umum Anutapura Palu.

\section{PEMBAHASAN}

Hasil penelitian ini ada hubungan inisiasi menyusu dini dengan produksi Air Susu Ibu pada post partum di Rumah Sakit Umum Anutapura Palu, karena dari hasil wawancara dengan responden, ibu sudah merasakan manfaat yang diperoleh ketika memberikan IMD pada bayinya. Selain itu ibu juga mendapatkan informasi dari bidan tentang manfaat IMD pada saat pelayanan antenatal care. Sedangkan ibu yang belum melakukan IMD karena ibu merasa takut dan malu dalam melakukan IMD disebabkan baru pertama kali melahirkan. Hasil penelitian ini sejalan dengan pendapat Nursiah 2012, alasan penting melakukan Inisiasi Menyusu Dini (IMD) adalah karena suhu dada ibu dapat menyesuaikan suhu ideal (thermogulator) yang diperlukan bayi. Kulit dada ibu yang melahirkan $1{ }^{\circ} \mathrm{C}$ lebih panas dari ibu yang tidak melahirkan. ${ }^{10}$ Jika bayinya kedinginan, suhu tubuh ibu otomatis naik $2^{\circ} \mathrm{C}$ untuk menghangatkan bayi, sehingga dapat menurunkan risiko hipotermia dan menurunkan kematian bayi akibat kedinginan.

Hasil penelitian ini sejalan dengan pendapat Kemenkes RI tahun 2012, IMD mencegah kematian bayi terutama dinegara berkembang. Praktek IMD dapat 
mencegah $22 \%$ angka kematian bayi baru lahir. ${ }^{2}$ Kehangatan dada ibu saat bayi diletakkan didada ibu, akan membuat bayi merasakan getaran cinta sehingga merasakan ketenangan, merasa dilindungi dan kuat secara psikis. Bayi akan lebih tenang, karena dengan mendengar pernapasan dan detak jantung ibu dapat menenangkan bayi, menurunkan stress akibat proses kelahiran dan meningkatkan kekebalan tubuh bayi. ${ }^{11}$ Bayi yang dibiarkan merayap diperut ibu dan menemukan puting susu ibunya sendiri, akan tercemar bakteri yang tidak berbahaya terlebih dahulu sebagai anti ASI ibu, sehingga bakteri baik ini membentuk koloni disusu dan kulit bayi. Hal ini berarti mencegah kolonisasi bakteri yang lebih ganas dari lingkungan. Pada saat bayi dapat menyusu segera setelah lahir, maka kolostrum makin cepat keluar sehingga bayi akan lebih cepat mendapatkan kolostrum ini, yaitu cairan pertama yang kaya akan antibody dan sangat penting untuk pertumbuhan usus dan ketahanan terhadap infeksi yang dibutuhkan bayi demi kelangsungan hidupnya. ${ }^{11}$

Menurut Roesli tahun 2012, bayi akan belajar menyusu dengan nalurinya sendiri. Sentuhan, kuluman/emutan dan jilatan pada puting ibu akan merangsang oksitosin ibu yang penting dalam menyebabkan kontraksi rahim, sehingga membantu pengeluaran plasenta dan mengurangi perdarahan, merangsang hormon lain yang membuat ibu merasa tenang, rileks dan merangsang pengaliran ASI dari payudara. ${ }^{3}$ Hasil penelitian ini sejalan dengan penelitian Arini tahun 2015, dengan hasil penelitian pada pelaksanaan IMD terdapat 15 ibu post partum $(50 \%)$ yang melaksanakan IMD dan 15 ibu post partum (50\%) yang tidak melaksanakan IMD di Desa Mranggen Kecamatan Jatinom Klaten. Dilihat dari produksi ASI sebagian besar adalah cukup 16 responden (53,3\%). Ada hubungan inisiasi menyusu dini dengan produksi ASI pada ibu post partum di Desa Mranggen Kecamatan Jatinom Klaten. ${ }^{12}$ Penelitian yang dilakukan oleh Tantina tahun 2015 yaitu rata-rata waktu pengeluaran ASI pertama 9,60 jam pada kelompok ibu yang IMD dan pada kelompok ibu yang tidak IMD 21,65 jam. Hasil penelitian tersebut juga di dapatkan ada pengaruh IMD terhadap waktu pengeluaran ASI pertama di wilayah kerja Puskesmas Bergas Kabupaten Semarang. ${ }^{5}$

Hasil penelitian hubungan rawat gabung dengan produksi air susu ibu pada post partum di rumah sakit umum anutapura palu, didapatkan hasil ada hubungan rawat gabung dengan produksi Air Susu Ibu pada post partum, Menurut analisa peneliti, ibu yang melakukan rawat gabung dengan bayinya karena ingin langsung dekat dengan anaknya. Kedekatan ibu dan anak akan menjalin kasih sayang yang lebih hangat sehingga ibu akan berusa memberikan Air Susunya kepada bayinya. Ibu yang tidak melakukan rawat gabung karena bayi ibu bermasalah seperti tidak dapat bernafas dengan spontan, hipotermi. Semakin cepat bayi dirawat gabung dengan ibunya maka akan meningkatkan kelancaran produksi ASI. ${ }^{2}$ Pada bulanbulan terakhir kehamilan sering ada sekresi kolostrum pada payudara ibu hamil. Setelah persalinan apabila bayi mulai menghisap payudara, maka produksi ASI bertambah secara cepat. Rawat gabung yang semakin cepat akan meningkatkan hormon pada payudara untuk memproduksi ASI. Makin sering isapan bayi, makin banyak produksi ASI. Sebaliknya, berkurangnya isapan bayi menyebabkan produksi ASI kurang. Mekanisme ini disebut mekanisme supply and demand.

Menurut Retno tahun 2017 rawat gabung membuat kontak emosi lebih dini dan lebih rapat. Makin sering dan makin lama proses menyusu diberikan maka kadar prolaktin akan tetap tinggi, ASI akan tetap diproduksi dan pancaran ASI akan lebih deras. ${ }^{6}$ Rangsangan pada puting susu melalui isapan bayi akan meningkatkan produksi prolaktin. Hormon ini merangsang sel-sel alveoli pada payudara yang 
berfungsi untuk membuat air susu. Pelaksanaan yang dilakukan rawat gabung akan meningkatkan hormon dan peningkatan rasa emosional ibu dan anak. Selain itu perawatan rawat gabung yang lebih cepat akan meningkatkan frekuensi hisapan bayi. Hal tersebut akan meningkatkan produksi ASI dibandingkan yang tidak dilakukan rawat gabung. Rawat gabung yang semakin cepat memungkinkan bayi untuk menghisap secara lebih cepat dan sering hal ini akan memperlancar produksi ASI. Penelitian ini juga sejalan dengan pendapat Muslihatun tahun 2012, tujuan rawat gabung adalah agar ibu dapat menyusui bayinya sedini mungkin, kapan saja dibutuhkan, agar ibu dapat melihat dan memahami cara perawatan bayi yang benar seperti yang dilakukan oleh petugas, agar ibu mempunyai kemampuan dan pengalaman dalam merawat bayinya sendiri selagi ibu masih dirawat dirumah sakit dan yang lebih penting bekal keterampilan merawat bayi serta menjalankannya setelah pulang dari rumah sakit, dalam perawatan gabung, suami dan keluarga dilibatkan secara aktif untuk mendukung dan membantu ibu dalam menyusui dan merawat bayinya secara baik dan benar, ibu mendapat kehangatan emosional karena ibu dapat selalu kontak dengan buah hati yang sangat dicintainya, demikian pula sebaliknya bayi dengan ibunya. ${ }^{13}$

Penelitian ini sejalan dengan penelitian Lusje tahun 2013 dengan hasil ibu yang dilakukan rawat gabung dan produksi ASInya lancar berjumlah 63 responden $(70 \%)$ sedangkan ibu yang tidak dilakukan rawat gabung namun produksi ASInya tidak lancar berjumlah 27 responden (30\%). Dapat dilihat bahwa ada hubungan rawat gabung dengan kelancaran ASI pada ibu post partum normal di BLU RSU Prof. DR. R.D. Kandau Manado. ${ }^{4}$

\section{SIMPULAN DAN SARAN}

Ada hubungan inisiasi menyusu dini dengan produksi Air Susu lbu pada post partum dan ada hubungan rawat gabung dengan produksi Air Susu lbu pada post partum di Rumah Sakit Umum Anutapura Palu. Saran penelitian adalah diharapkan bagi bidan di RSU Anutapura Kota Palu lebih meningkatkan perhatiannya terhadap tindakan skin to skin, memperhatikan bayi dalam mencari puting susu ibu dalam kurun waktu 1 jam setelah bayi lahir, sehingga angka keberhasilan IMD lebih meningkat dan program IMD ini menjadi lebih baik untuk keberhasilan pemberian ASI Eksklusif.

\section{DAFTAR PUSTAKA}

1. Kementerian Kesehatan R.I. Situasi dan Analisis ASI Ekslusif. Jakarta: Pusat Data Dan informasi Kementerian Kesehatan RI; 2014.

2. Kementerian Kesehatan R.I. Pedoman Pemberian Makanan Pendamping ASI (MP ASI. Jakarta: Kementerian Kesehatan R.I.; 2012.

3. Roesli U. ASI Panduan Praktis Ibu Menyusui. Yogyakarta: Banyu Media; 2012.

4. Lusje K, Mandang J, Kusmiyati K. Hubungan Rawat Gabung dengan Kelancaran Produksi ASI pada Ibu Post Partum Normal Di Irina D Bawah BLU RSUP Prof. Dr. R. D.Kandou Manado. J IIm Bidan. 2014;2(1):91801.

5. Tantina U, Siswanto Y, Susilo E. Pengaruh Inisiasi Menyusu Dini Terhadap Waktu Pengeluaran Asi Pertama Pada Ibu Post Partum Di Wilayah Kerja Puskesmas Bergas Kabupaten Semarang [Internet]. Sekolah Tinggi Ilmu Kesehatan Ngudi Waluyo Ungaran; 2015. Tersedia pada: http://ejournal.stikesngudiwaluyo.ac.id

6. Retno MS. Hubungan Rawat Gabung dengan Produksi ASI pada Ibu Nifas. IIm Keperawatan. 2017;3(2).

7. Rumah Sakit Umum Anutapura. Profil Rumah Sakit Anutapura Palu 2016. Palu; 2017.

8. Rumah Sakit Umum Anutapura. Profil Rumah Sakit Anutapura Palu 2015. Palu; 2016. 
9. Rumah Sakit Umum Anutapura. Profil Rumah Sakit Anutapura Palu 2014. Palu; 2015.

10. Nursiah. Asuhan Persalinan Normal Bagi Bidan. Bandung: Rafika Aditama; 2012.

11. Maryunani. Inisiasi Menyusu Dini, ASI Ekslusif, dan Manajemen Laktasi. Jakarta: Trans Info Media (TIM); 2012.

12. Arini MY. Hubungan Inisiasi Menyusu Dini Dengan Produksi Asi Pada Ibu Post Partum Di Desa Mranggen Kecamatan Jatinom Klaten [Internet]. Akademi Kebidanan Purworejo; 2015. Tersedia pada: https://e-journal.akbidpurworejo.ac.id/index.php/jkk7/article/view/57

13. Muslihatun. Asuhan Neonates Bayi dan Balita. Yogyakarta: Fitramaya; 2012. 